\title{
Review
}

\section{Energy Saving Aspects of Green Facades: Current Applications and Challenges}

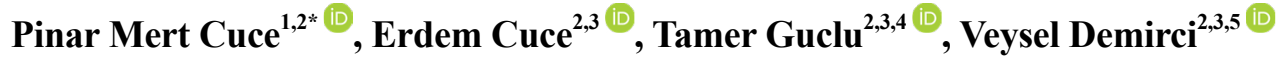 \\ ${ }^{1}$ Department of Architecture, Faculty of Engineering and Architecture, Recep Tayyip Erdogan University, Zihni Derin Campus, Rize, \\ Turkey \\ ${ }^{2}$ Low/Zero Carbon Energy Technologies Laboratory, Faculty of Engineering and Architecture, Recep Tayyip Erdogan University, \\ Zihni Derin Campus, Rize, Turkey \\ ${ }^{3}$ Department of Mechanical Engineering, Faculty of Engineering and Architecture, Recep Tayyip Erdogan University, Zihni Derin \\ Campus, Rize, Turkey \\ ${ }^{4}$ Department of Mechanical Engineering, Faculty of Engineering, Bayburt University, Dede Korkut Campus, Bayburt, Turkey \\ ${ }^{5}$ Department of Electricity and Energy, Arsin Vocational School, Karadeniz Technical University, Trabzon, Turkey \\ E-mail: pinar.mertcuce@erdogan.edu.tr
}

Received: 23 June 2021; Revised: 25 August 2021; Accepted: 9 September 2021

\begin{abstract}
One of the most effective key methods to meet today's increasing energy demands is to use resources efficiently. Especially in heating and cooling applications, notable energy savings are possible by efficient use of resources. For this purpose, insulation applications on building surfaces have been conducted for many years on a global scale. Besides, green facades are also considered to be one of the most suitable and efficient building cover technologies because of their superior benefits like energy saving, acoustic and thermal features, environmental aspects, and aesthetic appearance. Green facades are greenery media climbing over the facade, either traditionally or with special support structures. It is a highly preferred method in building coating applications, especially in recent years, but the initial installation and maintenance costs are somewhat expensive compared to traditional methods. Nevertheless, it still stands out as a cost-effective technology when its impacts on human health and environmental aspects are evaluated along with architectural features and social acceptance. Within the scope of this review, green facade systems are investigated in detail in terms of methodology, building applications, cost, challenges and potential solutions.
\end{abstract}

Keywords: buildings, green facades, energy saving, thermal comfort, human and environmental health

\section{Introduction}

Nowadays, efficient energy usage is extremely important besides energy supply. In buildings, the energy spent on heating and cooling systems is increasing due to structural design and application errors, environmental effects and climatic conditions. Hence, greenery systems are important in the context of reducing energy demand and life cycle carbon emissions, as committed in the 2015 Paris Agreement. Population growth and unplanned urbanisation create the heat island effect that causes disturbing weather conditions, as well as water, air and noise pollution. Therefore, the idea of creating a strong union between nature and city for sustainable urban life comes to the fore [1]. In this respect, greenery systems contribute to the urban landscape and offer people a more comfortable life. These systems, which were

Copyright (C2021 Pinar Mert Cuce, et al.

DOI: https://doi.org/10.37256/gbce.2220211007

This is an open-access article distributed under a CC BY license

(Creative Commons Attribution 4.0 International License)

https://creativecommons.org/licenses/by/4.0/ 
initially preferred due to their aesthetic appearance and shading effects, are now being evaluated and used for energy saving, climate rehabilitation, biodiversity support, and building material durability [2].

Previous studies have shown that some researchers focus on energy savings in vertical greenery systems. Under Mediterranean continental climatic conditions, in Spain, the results have shown that there is a remarkable opportunity for energy savings in summer months through green wall (58.9\%) and double-skin green facade (DSGF) (33.8\%) in comparison with the reference case without greenery. What is more, it has been observed that no extra energy is needed during the heating periods [3]. The green wall, also called the living wall in literature, is the system in which soil and irrigation infrastructures are provided to ensure the continuity of the plant along the wall plane. DSGFs, on the other hand, consist of a separate layer from the ground where the plant can hold and move along the facade without the need for soil and irrigation. In another work, it has been reported that energy saving rates for rooms with building envelope integrated green plants compared to reference rooms without greenery are 25 and $18 \%$ lower in summer and winter respectively [4]. The most common places where vegetation can be placed in buildings are roofs, facades, balconies, as well as atria where interior planting can be done [5], as shown in Figure 1. The main purpose of this paper is to present a comprehensive literature review in terms of the energy saving potential of green facades.

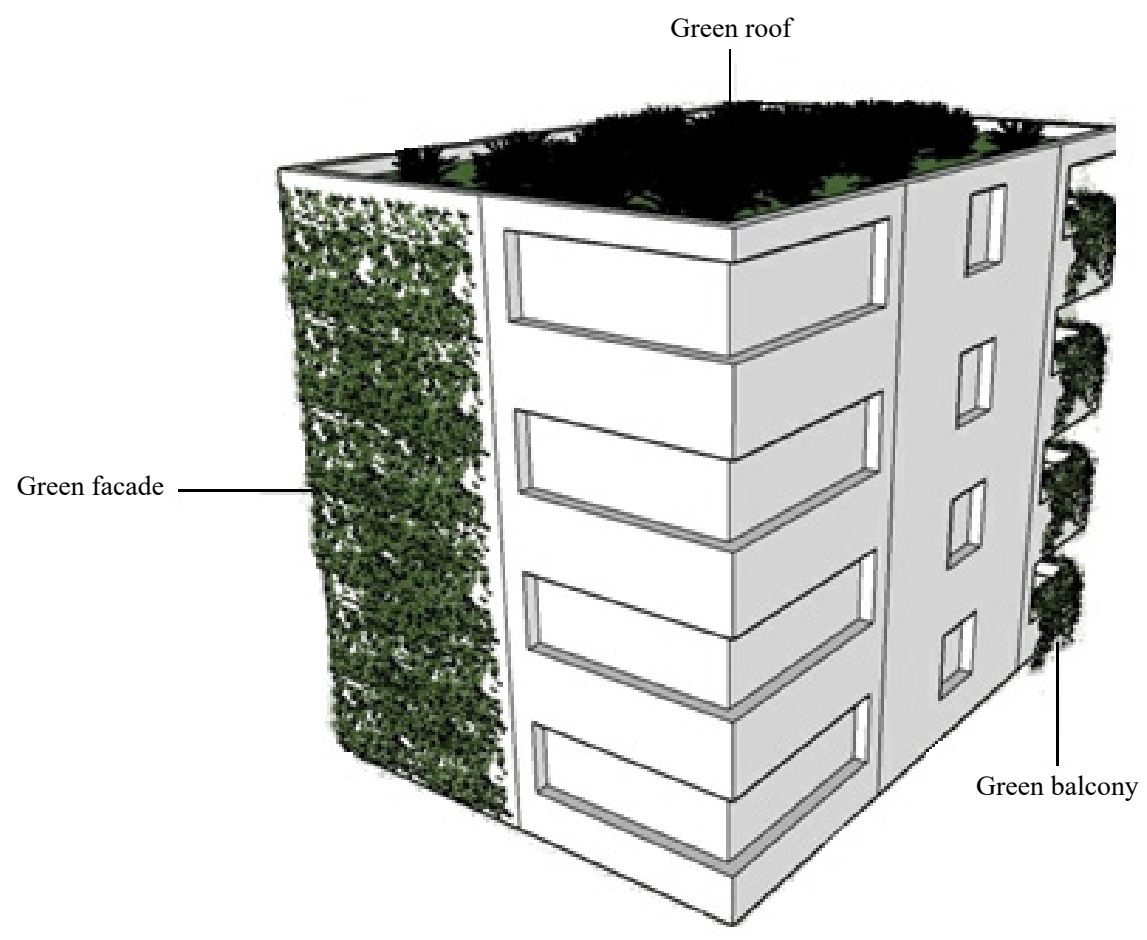

Figure 1. Potential methods to integrate greenery media to buildings.

\section{Greenery systems: methodology and green facades}

This review aims to thoroughly examine the remarkable studies in the literature related to greenery systems. In this context, the topics in the research cover classification, heat transfer models in terms of energy saving and selection of plant species. In addition, building applications, energy and environmental benefits, cost analysis, and challenges with potential solutions are discussed under different titles.

A green facade is described as a series of greenery structures climbing over the facade, either naturally or with some support elements. Manso and Castro-Gomes [6] have classified green facades as direct and indirect based on existing systems and construction features, as expressed in Table 1. Direct green facade is the type in which plants, such as ivy with small sticky roots, are attached to suitable attachment points on the surface of a wall and grow directly on 
it. An indirect green facade is a system that contains support structures such as modular trellis and continuous guides for vegetation, often with an air gap between the support structure and the wall, as shown in Figure 2 [7]. Another classification proposed by Perez et al. [8] splits green facades into three different systems; traditional green facades, DSGFs, and perimeter flowerpots. Supporters used for DSGFs are modular trellis, wired, and mesh structures.

Table 1. The classification of green facades [6]

\begin{tabular}{cc}
\hline \multicolumn{2}{c}{ Green facades } \\
Direct & Indirect \\
\hline Traditional green facade & Continuous guides \\
& Modular trellis \\
\hline
\end{tabular}
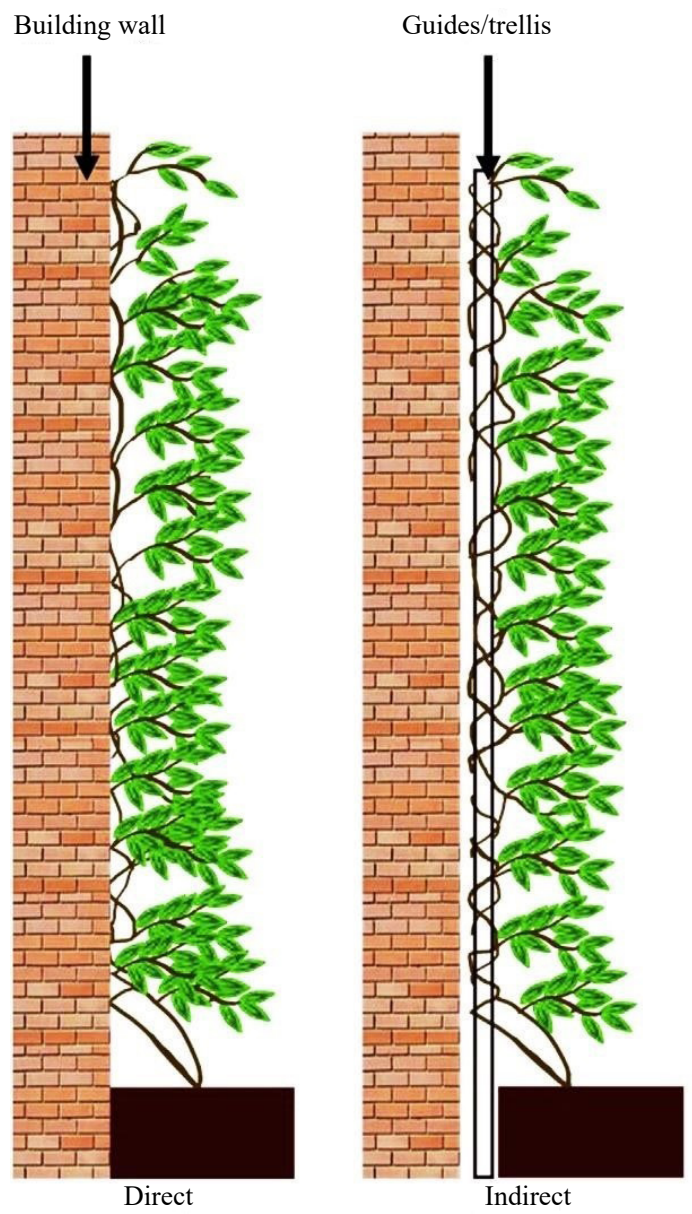

Figure 2. Schematic diagram of green facade examples [7].

When the green facades have been examined in terms of energy saving, three important aspects are addressed by assessors as key factors: evapotranspiration, shading effect and thermal insulation [5]. In another work, four basic mechanisms have been expressed for vertical greenery systems (green facades and living walls): shadow influence supplied by the vegetation, thermal resistance maintained by substrate and vegetation, evapotranspiration assisted evaporative cooling, and variation of the wind effect on the building through its blockage [8]. Susorova et al. [9] have presented a mathematical model that considers many parameters to evaluate heat transfer in green facades for optimal 
energy efficiency. The parameters proposed in the mathematical model for physical and thermal processes are: solar radiation penetration through the greenery layer; infrared radiation exchange between the sky and facade, the ground and facade, and the facade and greenery surface; convection from and to the facade; evapotranspiration from the greenery surface; heat conduction through the facade; and heat storage in the facade material.

Studies on greenery systems deal with a wide range of factors such as the leaf shape and dimension, rate of growth, reachable height, temperature tolerance in winter, maintenance, orientation or sun preference, climatic tolerance, and soil selection based on plant species [10]. The type of vertical greenery systems is important, as soil depth and supporting structure are also decisive factors in plant selection. Climbing plants such as Hedera helix, Parthenocissus quinquefolia and Ficus pumila are required in the design of green facades [11]. For vertical greenery systems, maintenance and environmental conditions are important for the long-term survivability of the plants and in terms of fire safety [12]. Irrigation is of vital importance in this regard. Insufficient irrigation and environmental effects can dry out plants, and fire spread can be a potential hazard.

Dahanayake et al. [11] have expressed that the selection of plant species has a significant effect on the performance of vertical foliage structures. The characteristics of plants can be categorized into four groups: structural factors, radiative features, plant properties and processes [11]. Additionally, they have expressed that if the leaf area index (LAI) associated with the structural parameter is high, the energy saving is also high. The illustrative description of LAI is as shown in Figure 3 [13]. LAI is a dimensionless quantity which has been defined as the ratio of leaf area to the ground surface area $\left(\mathrm{LAI}=\right.$ leaf area $\left(\mathrm{m}^{2}\right) /$ ground area $\left.\left(\mathrm{m}^{2}\right)\right)$. Another effective factor in measuring thermal performance is the coverage rate $(\mathrm{Cr})$, which is defined as the percentage of the plant-covered area to the total surface area [14,15]. Table 2 shows the examples of plant species that were used in the studies of the green facades [16-20].

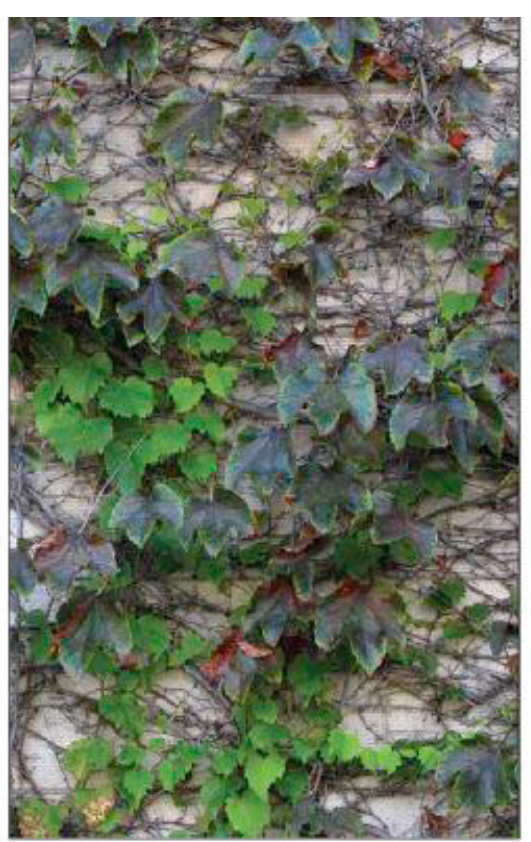

LAI $\sim 0.25$

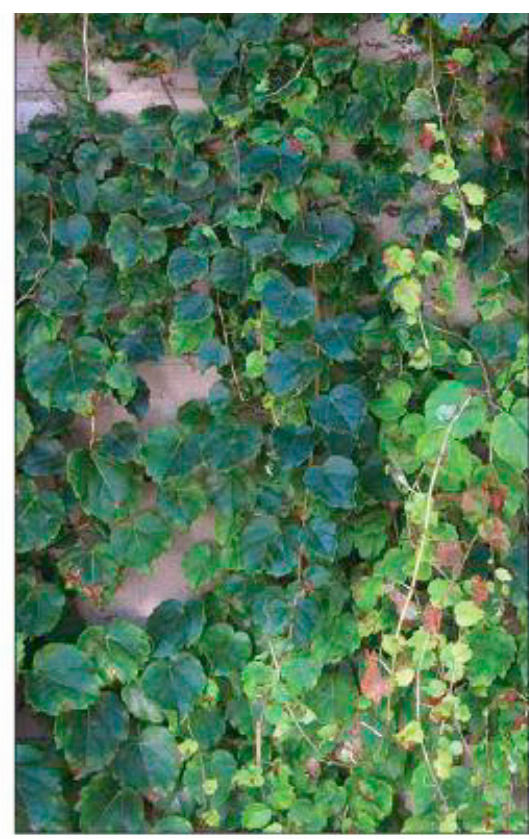

LAI $\sim 0.75$

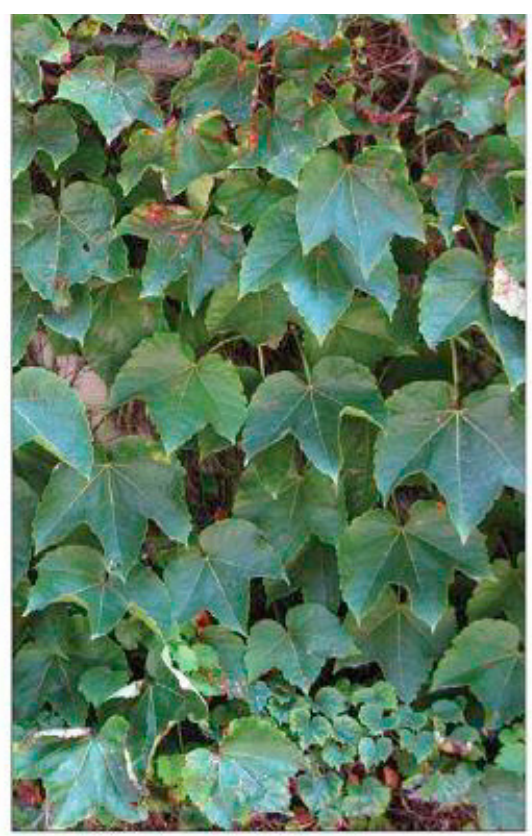

LAI $\sim 1.5$

Figure 3. Illustrative description of leaf area index (LAI) [13] 
Table 2. Plant species considered as green facades in literature

\begin{tabular}{|c|c|c|c|c|c|}
\hline $\begin{array}{l}\text { Type of green } \\
\text { facades }\end{array}$ & Type of study & Plant type & Selection criteria & $\begin{array}{l}\text { Factors examined } \\
\text { (keywords) }\end{array}$ & Ref. \\
\hline Indirect & Experimental & - Virginia Creeper & $\begin{array}{l}\text { - Suitable for UK climate } \\
\text { - Better shading }\end{array}$ & - Bioshading coefficient & [10] \\
\hline Indirect (DSGF) & Experimental & $\begin{array}{l}\text { - Ivy (Hedera helix) } \\
\text { - Honeysuckle (Lonicera } \\
\text { japonica) } \\
\text { - Boston Ivy } \\
\text { - Clematis }\end{array}$ & $\begin{array}{l}\text { - Reachable height } \\
\text { - Suitability to live in modular trellis } \\
\text { - Availability in nurseries } \\
\text { - Resistance of the greenery }\end{array}$ & $\begin{array}{l}\text { - Wall surface } \\
\text { temperature } \\
\text { - Energy consumption }\end{array}$ & [16] \\
\hline Indirect & $\begin{array}{l}\text { Experimental } \\
\text { and analytical }\end{array}$ & - Bean (Phaseolus Vulgaris L) & $\begin{array}{l}\text { - Adaptation to local climate } \\
\text { - Fast growing } \\
\text { - A thick canopy }\end{array}$ & $\begin{array}{l}\text { - Thermal response } \\
\text { - Heat flux } \\
\text { - Cooling effect }\end{array}$ & [17] \\
\hline $\begin{array}{l}\text { Direct } \\
\text { (traditional green } \\
\text { facade) }\end{array}$ & $\begin{array}{l}\text { Experimental } \\
\text { and numerical }\end{array}$ & - Ivy (Hedera helix) & $\begin{array}{l}\text { - Well-grown evergreen climbing } \\
\text { plant }\end{array}$ & $\begin{array}{l}\text { - Thermal regulation } \\
\text { - Wall temperatures }\end{array}$ & [18] \\
\hline Indirect & $\begin{array}{l}\text { Experimental } \\
\text { and analytical }\end{array}$ & $\begin{array}{l}\text { - Pandorea jasminoides } \\
\text { - Rhyncospermum jasminoides }\end{array}$ & $\begin{array}{l}\text { - Climbing ability } \\
\text { - Strong growth } \\
\text { - Fast development } \\
\text { - Good adaptation to the } \\
\text { environmental changes }\end{array}$ & $\begin{array}{l}\text { - Lower surface } \\
\text { temperature } \\
\text { - Cooling effect }\end{array}$ & [19] \\
\hline $\begin{array}{l}\text { Direct } \\
\text { Indirect (DSGF) }\end{array}$ & Experimental & $\begin{array}{l}\text { - Parthenocissus tricuspidata } \\
\text { and Hedera helix (for direct) } \\
\text { - Fallopia baldschuanica (for } \\
\text { indirect) }\end{array}$ & $\begin{array}{l}\text { Ability to climb by clinging to the } \\
\text { facade (for P. tricuspidata and } H \text {. } \\
\text { helix) } \\
\text { - Very fast growth but needs climbing } \\
\text { aids for its upward growth (for } F \text {. } \\
\text { baldschuanica) }\end{array}$ & $\begin{array}{l}\text { - Cooling effect } \\
\text { - Shading } \\
\text { - Transpiration } \\
\text { - Insulation }\end{array}$ & [20] \\
\hline
\end{tabular}

\section{Building applications of green facades}

The popularity of green facade is increasing day by day due to the physical, chemical and biological risks that occur in urban life. The green facade protects the environment by absorbing dust and pollutants in the air, and it plays an influential role in noise mitigation, which has negative effects on human health. Additionally, green facade provides a sustainable urban life by enabling significant energy savings during the heating and cooling periods of the buildings. The green facade is also designed with architectural and aesthetic concerns. As a result, the green facade has many advantages for a more sustainable ecosystem. Dahanayake and Chow [21] have evaluated the applications of vertical greenery systems in Hong Kong by categorising them under commercial, institutional, residential and government buildings. There are many applications of green facades in different regions of the world.

The effect of DSGF application on cooling performance in summertime of an administrative building (shown in Figure 4) on the university campus in Shanghai, which has a warm and humid subtropical climate, has been investigated. When evaluating the green facade effect, a thermal improvement was observed with an average of $1.1^{\circ} \mathrm{C}$ and a maximum of $2.7^{\circ} \mathrm{C}$ in the south-facing office, and an average of $0.6^{\circ} \mathrm{C}$ and a maximum of $1.9^{\circ} \mathrm{C}$ in the northfacing office [22]. Li et al. [23] have investigated the impact of leaf thickness on the thermal behaviour of traditional green facades in two-story building, as shown in Figure 5, with a south-facing wall covered with Boston ivy at Suzhou University of Science and Technology, China. Compared to the bare wall, a maximum temperature reduction of $6.3{ }^{\circ} \mathrm{C}$ has been observed on the surface of the thickest exterior wall with a foliage thickness of $19.8 \mathrm{~cm}$. Perez et al. [24] have examined a building in the village of Golmés, near Lleida City, Spain, that was restored for social activities and had vegetation incorporated into its facade (DSGF), as depicted in Figure 6. According to the results, the air in the interspace creates a microclimate, with higher temperatures and lower relative humidity in the winter and lower temperatures and higher relative humidity in the summer. In their examination of vertical gardens, Timur and Karaca [25] have included images of some green facade designs, such as the Ex Ducati Office in Italy, where the grid system is applied as a supporter to the facade, which is an application of indirect green facades. 

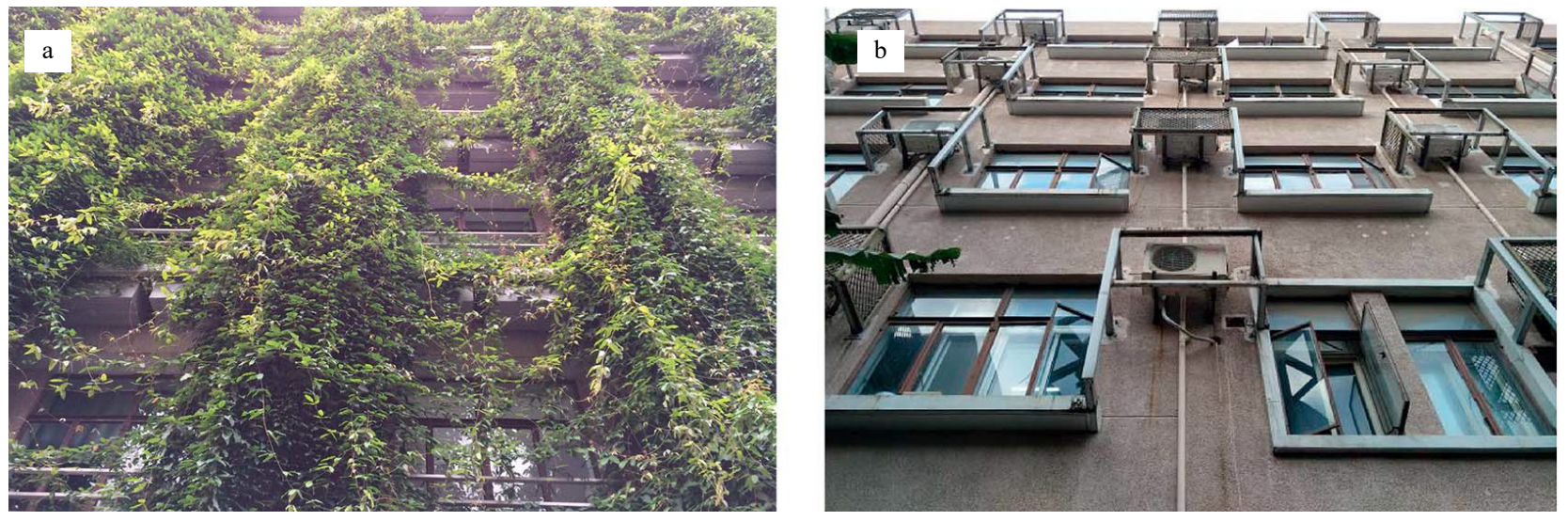

Figure 4. (a) DSGF and (b) original bare facade [22]
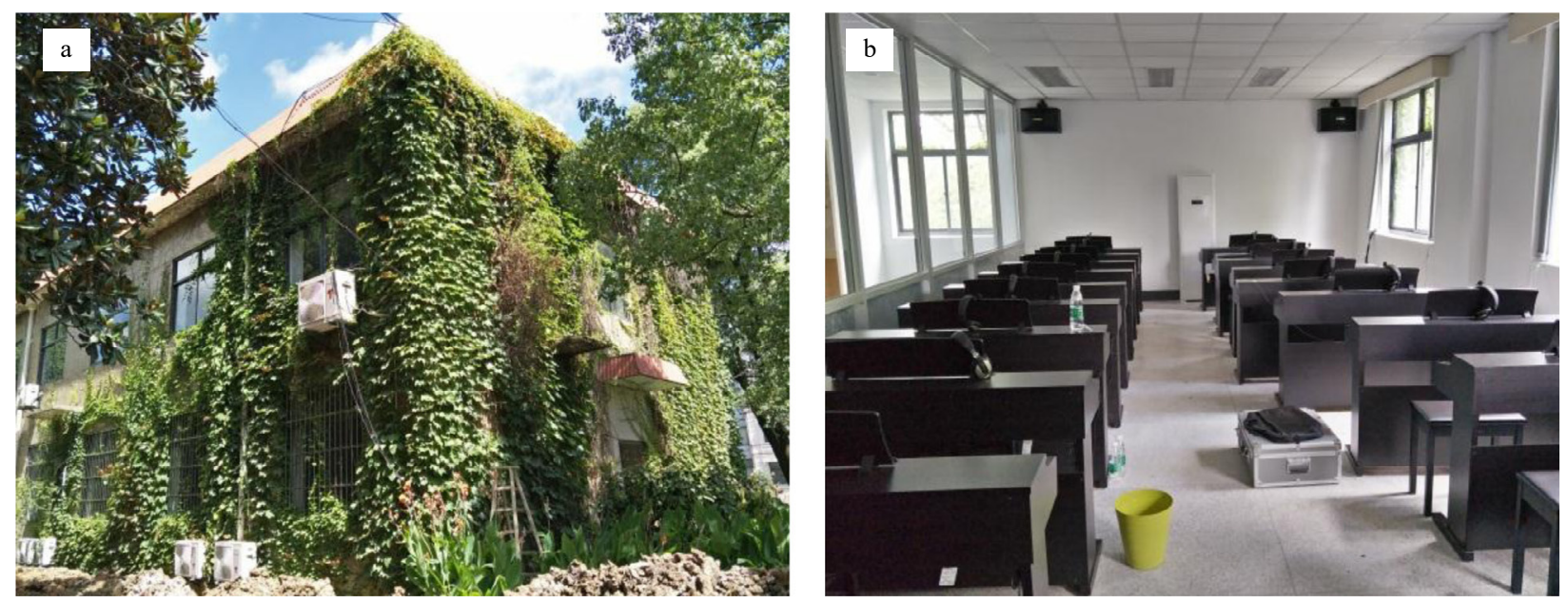

Figure 5. (a) Appearance and (b) interior of tested wall (traditional green facade) in Suzhou [23]

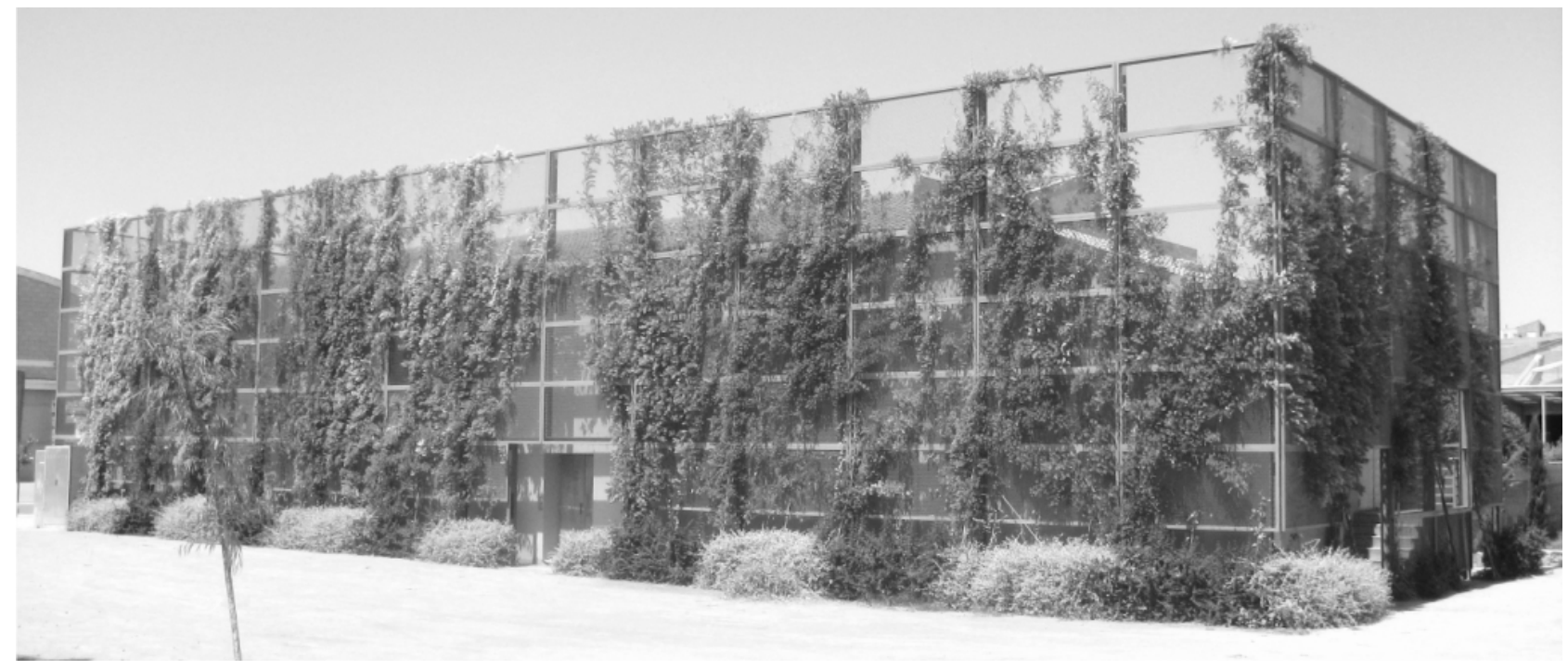

Figure 6. Lo Casal de Golmés Theatre with DSGF in Spain [24] 


\section{Energy and environmental benefits}

The plants are more beneficial than synthetic materials like metal or plastic for building facades in terms of energy and environmental features. Unlike synthetic materials, a vegetative facade ensures coolness in the surrounding buildings since it does not reflect the heat of solar radiation [26]. The green facade assists in the mitigation of the energy consumption of buildings by providing control of the building temperature at the desired values [27]. Since it acts as a barrier against heat transfer from the inside to the outside or from the outside to the inside, it helps to reduce heating and cooling costs and thus the amount of energy consumption in buildings [28]. The green facade also functions as an acoustic barrier, which enhances internal comfort and improves property values. The plants protect the facades from the presence of ultraviolet radiation, humidity, high temperature fluctuations and rain [29]. If green facade is assessed in terms of environmental aspects, it can be underlined that it contributes to the reduction of air pollution and urban heat island effect by improving air quality, minimising dust and heavy metal accumulation in the air, and filtering airborne particles. In addition to this, green facade plants act as a habitat for various colonising species and, thanks to this habitat, help to create healthy living spaces and protect urban biodiversity [30].

Yang et al. [22] have conducted an investigation to evaluate the thermal and energetic performance of a DSGF. The study was carried out in the summertime at a university campus in Shanghai. According to the experimental findings, vertical greening systems create a microclimate zone in the cavity. They have also shown that DSGF can ensure a $0.4^{\circ} \mathrm{C}$ temperature drop in the daily cycle for the average indoor air temperature. With the presence of a green facade, it can be said that while the cooling energy needs of the buildings decrease, the thermal comfort can be improved. Xing et al. [31] have conducted an experimental study to examine the thermal and energy performance of green facade systems. They have performed comparative experiments to observe how the vertical greenery systems affected the energy consumption and indoor climate conditions of the buildings under several winter weather situations. They prepared two similar test rooms in Hunan Province, China, and covered one room with a vertical greening system. From the experimental test results, the room covered with a green facade has shown a temperature increment of 1 to $3^{\circ} \mathrm{C}$ than the non-covered room during the night. It has been noticed in the study that $18 \%$ energy savings can be achieved with the extra thermal resistance maintained by the greenery system. In another study, Azkorra et al. [32] have investigated the acoustic performance of green walls. According to their study, about $15 \mathrm{~dB}$ reduction in noise level is possible with vertical greening systems. On the other hand, it has been reported that in order to provide sufficient acoustic isolation, the joints between the modular pieces should be well sealed.

\section{Cost analysis}

The cost of green facade applications generally covers the installation, operation, maintenance and disposal expenses. The installation and maintenance expenses of greenery systems are generally higher compared to traditional cladding systems. However, when a comparative life-cycle cost analysis is done between these systems, all of the conditions that directly affect human life, such as economic, environmental, social and health, should be evaluated together. For example, a coating material that is produced at a lower cost than a green wall may be more environmentally hazardous, whereas a visually aesthetic material may not provide excellent sound insulation. Thus, a green wall can be considered a cost-effective technology when considering the environmental, social, and health benefits it provides [33]. In a review study, Manso et al. [34] have summarised the costs of the green facade and green roof systems under three main categories, as shown in Table 3.

Rosasco and Perini [35] have investigated the financial sustainability of a vertical greenery unit integrated into an office building in Italy via a cost-benefit approach. They have compared the benefits of green facades against the costs of installation, operation and maintenance, disposal, and taxes. According to the results, the most important economic indicators are the increase in property value and the decrease in energy costs against the annual maintenance expenses and biomass production. They also indicated that if the government applies tax reductions on installation costs, green facades can be economically sustainable. Teotonio et al. [36] have conducted a literature study to examine green roofs and green facades in terms of economic aspects. According to their study, green facades are generally considered an expensive technology when evaluated economically alone. However, when considered together with its ecological, 
social and health benefits, it emerges as a reliable and cost-effective technology

Table 3. Cost analysis of green facade and green roof systems [34]

\begin{tabular}{lccc}
\hline & Green facade & Extensive green roof & Intensive green roof \\
\hline Installation $\left(€ / \mathrm{m}^{2}\right)$ & 190 & 99 & 362 \\
Operation and maintenance $\left(€ / \mathrm{m}^{2} /\right.$ year $)$ & 557 & 428 & 564 \\
Disposal $\left(€ / \mathrm{m}^{2}\right)$ & 95 & 12 & 26 \\
\hline
\end{tabular}

\section{Challenges and solutions}

The main challenges of green facade systems can be classified as economic, pruning and irrigation, fire hazard and insect growth. When the green facade is evaluated in terms of economic aspects, this system is more expensive than other covering technologies. Green facade costs include the initial cost of the plant, as well as nutrient and watering system expenses [37]. If an indirect green facade system is chosen, construction expenses are added to the overall system. Reducing these initial installation and maintenance costs is very important in terms of ensuring sustainable green facade applications. The best precaution that can be taken for this purpose is to choose the most suitable plant for the region. If an indirect green facade system is selected, the construction system should be produced with the optimum thickness and most cost-effective material. In addition to these measures, it may be suggested that governments provide tax reductions and support payments to make green facade a more competitive option than the other coating technologies.

One of the most important challenges in green facade applications is irrigation systems. Irrigation systems deliver water and nutrients to plants' roots, allowing them to grow. Both initial setup costs and maintenance costs during utilisation require significant budgets [38]. The amount of water consumed during the irrigation process is also important. The most important way to reduce these expenses is to choose the plant that needs the least amount of water in the region where the green façade is applied. In addition, drip irrigation methods can be applied to reduce water consumption and installation costs.

The pruning of plants used in green facade applications poses difficulties, especially in high-rise building applications. When plants that have received an adequate amount of water and nutrients continue to grow and are not pruned, they will take up too much volume and add weight. This endangers the structure and stability of the green façade system [39]. For this reason, the plants should be pruned on a regular basis. Pruning intervals can be extended by selecting suitable woody plants with minimal branch growth.

Another issue that needs to be considered for the green facade system to be sustainable is fire safety [40]. A fire safety system is the measure taken to ensure that the building and its green walls are saved with minimal damage in case of a possible fire. Structure materials used in indirect green facade systems can cause the system to collapse, even in small fires. To address this issue, some countries have amended their fire laws. With the newly arranged laws, aluminium panels were chosen to replace plastic panels [41]. Governments in all countries should review their fire laws and impose the use of fire-resistant materials and non-combustible paints.

Green facade applications, in addition to providing thermal, acoustic, environmental, and health benefits, also help beneficial insect species such as honey bees and ladybugs to find a habitat, thereby increasing their numbers, pollination, and food production [42]. However, unwanted insects and snakes can also create habitats on these fronts. For this reason, it is recommended to begin green facade applications from a certain height off the ground, use an indirect system instead of a direct system, spray the plants regularly, and use protectors on building openings like windows.

\section{Conclusion}

This study provides a review of green facades in terms of methodology, applications, cost analysis, and challenges based on the last ten years of literature. Green facade is one of the most suitable and efficient building cover technologies 
because of its superior advantages such as energy saving, thermal and acoustic insulation, environmental benefits, and aesthetic appearance. Although the initial investment and maintenance costs of green façade are more expensive (average cost of $290 € / \mathrm{m}^{2}$ per year) compared to traditional materials such as metal or plastic, it is still a cost-effective technology that is commended for its aesthetic appearance, superior heat and sound insulation, environmentally friendliness and health benefits. On the other hand, the main challenges of the green facade system can be listed as economic, pruning and irrigation, fire hazard, and insect growth. It may be advisable for governments to make incentive tax cuts and support payments to make it economically competitive with other coating technologies. In addition, for indirect systems, the most cost-effective material and the least water-consuming plant suitable for the application area should be selected. Also, regular spraying and coating after a certain height off the ground are recommended for the plants to protect them against harmful pest, insect and reptile hazards.

\section{References}

[1] Wong NH, Tan AY, Chen Y, Sekar K, Tan PY, Chan D, et al. Thermal evaluation of vertical greenery systems for building walls. Building and environment. 2010; 45(3): 663-672. Available from: doi: 10.1016/ j.buildenv.2009.08.005.

[2] Pérez G, Coma J, Martorell I, Cabeza LF. Vertical Greenery Systems (VGS) for energy saving in buildings: A review. Renewable and sustainable energy reviews. 2014; 39: 139-165. Available from: doi: 10.1016/ j.rser.2014.07.055.

[3] Coma J, Pérez G, de Gracia A, Burés S, Urrestarazu M, Cabeza LF. Vertical greenery systems for energy savings in buildings: A comparative study between green walls and green facades. Building and environment. 2017; 111: 228237. Available from: doi: 10.1016/j.buildenv.2016.11.014.

[4] Tan H, Hao X, Long P, Xing Q, Lin Y, Hu J. Building envelope integrated green plants for energy saving. Energy Exploration \& Exploitation. 2020; 38(1) :222-234. Available from: doi: 10.1177/0144598719875529.

[5] Raji B, Tenpierik MJ, van den Dobbelsteen A. The impact of greening systems on building energy performance: A literature review. Renewable and Sustainable Energy Reviews. 2015; 45: 610-623. Available from: doi: 10.1016/ j.rser.2015.02.011.

[6] Manso M, Castro-Gomes J. Green wall systems: A review of their characteristics. Renewable and sustainable energy reviews. 2015; 41: 863-871. Available from: doi: 10.1016/j.rser.2014.07.203.

[7] Bustami RA, Belusko M, Ward J, Beecham S. Vertical greenery systems: A systematic review of research trends. Building and Environment. 2018; 146: 226-237. Available from: doi: 10.1016/j.buildenv.2018.09.045.

[8] Perez G, Rincon L, Vila A, Gonzalez JM, Cabeza LF. Green vertical systems for buildings as passive systems for energy savings. Applied energy. 2011; 88(12): 4854-4859. Available from: doi: 10.1016/j.apenergy.2011.06.032.

[9] Susorova I, Angulo M, Bahrami P, Stephens B. A model of vegetated exterior facades for evaluation of wall thermal performance. Building and Environment. 2013; 67: 1-13. Available from: doi: 10.1016/j.buildenv.2013.04.027.

[10] Ip K, Lam M, Miller A. Shading performance of a vertical deciduous climbing plant canopy. Building and Environment. 2010; 45(1): 81-88. Available from: doi: 10.1016/j.buildenv.2009.05.003.

[11] Dahanayake KC, Chow CL, Hou GL. Selection of suitable plant species for energy efficient Vertical Greenery Systems (VGS). Energy Procedia. 2017; 142: 2473-2478. Available from: doi: 10.1016/j.egypro.2017.12.185.

[12] Department for Communities and Local Government. Fire Performance of Green Roofs and Walls. Ministry of Housing, Communities \& Local Government. 2013.

[13] Zazzini P, Grifa G. Energy Performance Improvements in Historic Buildings by Application of Green Walls: Numerical Analysis of an Italian Case Study. Energy Procedia. 2018; 148: 1143-1150. Available from: doi: 10.1016/j.egypro.2018.08.028.

[14] Koyama T, Yoshinaga M, Hayashi H, Maeda KI, Yamauchi A. Identification of key plant traits contributing to the cooling effects of green façades using freestanding walls. Building and Environment. 2013; 66: 96-103. Available from: doi: 10.1016/j.buildenv.2013.04.020.

[15] Zheng X, Dai T, Tang M. An experimental study of vertical greenery systems for window shading for energy saving in summer. Journal of Cleaner Production. 2020; 259: 120708. Available from: doi: 10.1016/j.jclepro.2020.120708.

[16] Coma J, Pérez G, Solé C, Castell A, Cabeza LF. New green facades as passive systems for energy savings on buildings. Energy procedia. 2014; 57: 1851-1859. Available from: doi: 10.1016/j.egypro.2014.10.049.

[17] Šuklje T, Medved S, Arkar C. On detailed thermal response modeling of vertical greenery systems as cooling 
measure for buildings and cities in summer conditions. Energy. 2016; 115: 1055-1068. Available from: doi: 10.1016/j.energy.2016.08.095.

[18] Cuce E. Thermal regulation impact of green walls: An experimental and numerical investigation. Applied Energy. 2017; 194: 247-254. Available from: doi: 10.1016/j.apenergy.2016.09.079.

[19] Blanco I, Schettini E, Vox G. Predictive model of surface temperature difference between green façades and uncovered wall in Mediterranean climatic area. Applied Thermal Engineering. 2019; 163: 114406. Available from: doi: 10.1016/j.applthermaleng.2019.114406.

[20] Hoelscher MT, Nehls T, Jänicke B, Wessolek G. Quantifying cooling effects of facade greening: Shading, transpiration and insulation. Energy and Buildings. 2016; 114: 283-290. Available from: doi: 10.1016/ j.enbuild.2015.06.047.

[21] Dahanayake KW, Chow CL. A brief discussion on current vertical greenery systems in Hong Kong: the way forward. Sustainable Energy. 2015; 136-147.

[22] Yang F, Yuan F, Qian F, Zhuang Z, Yao J. Summertime thermal and energy performance of a double-skin green facade: A case study in Shanghai. Sustainable Cities and Society. 2018; 39: 43-51. Available from: doi: 10.1016/ j.scs.2018.01.049.

[23] Li C, Wei J, Li C. Influence of foliage thickness on thermal performance of green façades in hot and humid climate. Energy and Buildings. 2019; 199: 72-87. Available from: doi: 10.1016/j.enbuild.2019.06.045.

[24] Pérez G, Rincón L, Vila A, González JM, Cabeza LF. Behaviour of green facades in Mediterranean Continental climate. Energy conversion and management. 2011; 52(4): 1861-1867.

[25] Timur ÖB, Karaca E. Vertical gardens. In: Özyavuz M. (ed.) Advances in Landscape Architecture. United Kingdom: IntechOpen; 2013. Available from: doi: 10.5772/55763.

[26] Widiastuti R, Caesarendra W, Prianto E, Budi WS. Study on the leaves densities as parameter for effectiveness of energy transfer on the green facade. Buildings. 2018; 8(10): 138. Available from: doi: 10.3390/buildings8100138.

[27] Perini K, Ottelé M, Haas EM, Raiteri R. Vertical greening systems, a process tree for green façades and living walls. Urban Ecosystems. 2013; 16(2): 265-277. Available from: doi: 10.1007/s11252-012-0262-3.

[28] He Y, Yu H, Ozaki A, Dong N, Zheng S. An investigation on the thermal and energy performance of living wall system in Shanghai area. Energy and Buildings. 2017; 140: 324-335. Available from: doi: 10.1016/ j.enbuild.2016.12.083.

[29] Bevilacqua P, Mazzeo D, Bruno R, Arcuri N. Surface temperature analysis of an extensive green roof for the mitigation of urban heat island in southern mediterranean climate. Energy and Buildings. 2017; 150: 318-327. Available from: doi: 10.1016/j.enbuild.2017.05.081.

[30] Vox G, Blanco I, Schettini E. Green façades to control wall surface temperature in buildings. Building and Environment. 2018; 129: 154-166. Available from: doi: 10.1016/j.buildenv.2017.12.002.

[31] Xing Q, Hao X, Lin Y, Tan H, Yang K. Experimental investigation on the thermal performance of a vertical greening system with green roof in wet and cold climates during winter. Energy and Buildings. 2019; 183: 105117. Available from: doi: 10.1016/j.enbuild.2018.10.038.

[32] Azkorra Z, Pérez G, Coma J, Cabeza LF, Burés S, Álvaro JE, et al. Evaluation of green walls as a passive acoustic insulation system for buildings. Applied Acoustics. 2015; 89: 46-56. Available from: doi: 10.1016/ j.apacoust.2014.09.010.

[33] Besir AB, Cuce E. Green roofs and facades: A comprehensive review. Renewable and Sustainable Energy Reviews. 2018; 82: 915-939. Available from: doi: 10.1016/j.rser.2017.09.106.

[34] Manso M, Teotónio I, Silva CM, Cruz CO. Green roof and green wall benefits and costs: A review of the quantitative evidence. Renewable and Sustainable Energy Reviews. 2021; 135: 110111. Available from: doi: 10.1016/j.rser.2020.110111.

[35] Rosasco P, Perini K. Evaluating the economic sustainability of a vertical greening system: A Cost-Benefit Analysis of a pilot project in mediterranean area. Building and Environment. 2018; 142: 524-533. Available from: doi: 10.1016/j.buildenv.2018.06.017.

[36] Teotónio I, Silva CM, Cruz CO. Economics of green roofs and green walls: A literature review. Sustainable Cities and Society. 2021; 69: 102781. Available from: doi: 10.1016/j.scs.2021.102781.

[37] Perini K, Rosasco P. Cost-benefit analysis for green façades and living wall systems. Building and Environment. 2013; 70: 110-121. Available from: doi: 10.1016/j.buildenv.2013.08.012.

[38] Rakhshandehroo M, Mohd Yusof MJ, Deghati Najd M. Green façade (Vertical Greening): Benefits and Threats. Applied Mechanics and Materials. 2015; 747: 12-15. Available from: doi: 10.4028/www.scientific.net/amm.747.12.

[39] Amorim F, Mendonça P. Advantages and constraints of living green façade systems. International Journal of 
Environmental Science and Development. 2017; 8(2): 124-129. Available from: doi: 10.18178/ijesd.2017.8.2.933.

[40] Van de Wouw PM, Ros EJ, Brouwers HJ. Precipitation collection and evapo (transpi) ration of living wall systems: A comparative study between a panel system and a planter box system. Building and Environment. 2017; 126: 221237. Available from: doi: 10.1016/j.buildenv.2017.10.002.

[41] Chew MY, Conejos S, Azril FH. Design for maintainability of high-rise vertical green facades. Building Research \& Information. 2019; 47(4): 453-467. Available from: doi: 10.1080/09613218.2018.1440716.

[42] Ridzuan NH, Farouk SA, Razak SA, Avicor SW, Taib N, Hamzah SN. Insect biodiversity of urban green spaces in Penang Island, Malaysia. International Journal of Tropical Insect Science. 2021: 1-10. Available from: doi: 10.1007/s42690-021-00543-2. 